\title{
Habitat selection by owls in a seasonal semi-deciduous forest in southern Brazil
}

\author{
W. Menq ${ }^{a *}$ and L. Anjos ${ }^{b}$ \\ aPrograma de Pós-graduação em Ciências Biológicas, Universidade Estadual de Londrina - UEL, \\ CP 10011, CEP 86057-970, Londrina, PR, Brazil

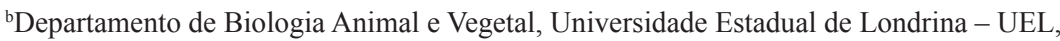 \\ CP 10011, CEP 86057-970, Londrina, PR, Brazil \\ *e-mail: willianmenq@gmail.com
}

Received: May 2, 2014 - Accepted: July 24, 2014 - Distributed: November 30, 2015

(With 4 figures)

\begin{abstract}
This paper tested the hypothesis that the structural components of vegetation have impact over the distribution of owl species in a fragment of a semi-deciduous seasonal forest. This paper also determined which vegetation variables contributed to the spatial distribution of owl species. It was developed in the Perobas Biological Reserve (PBR) between September and December 2011. To conduct the owl census, a playback technique was applied at hearing points distributed to cover different vegetation types in the study area. A total of 56 individual owls of six species were recorded: Tropical Screech-Owl (Megascops choliba), Black-capped Screech-Owl (Megascops atricapilla), Tawnybrowed Owl (Pulsatrix koeniswaldiana), Ferruginous Pygmy-Owl (Glaucidium brasilianum), Mottled Owl (Strix virgata) and Stygian Owl (Asio stygius). The results suggest that the variables of vegetation structure have impact on the occurrence of owls. The canopy height, the presence of hollow trees, fallen trees and glades are the most important structural components influencing owl distribution in the sampled area.
\end{abstract}

Keywords: vegetation structure, seasonal semi-deciduous forest, Perobas Biological Reserve, Strigiform.

\section{Seleção de habitat por corujas em uma floresta estacional semidecidual no sul do Brasil}

\section{Resumo}

Este estudo testou a hipótese de que os componentes estruturais da vegetação de uma floresta influenciam a distribuição das espécies de corujas de um fragmento de floresta estacional semidecidual. O estudo também determinou quais variáveis da vegetação contribuem na distribuição espacial das espécies. O estudo foi desenvolvido na Reserva Biológica das Perobas, entre os meses de setembro e dezembro de 2011. Para realizar o censo das corujas foi utilizada a técnica de playback em pontos de escuta dispostos de modo a abranger os diferentes tipos de vegetação na área de estudo. Foi encontrado um total de 56 indivíduos de seis espécies de corujas: corujinha-do-mato (Megascops choliba), corujinha-sapo (Megascops atricapilla), murucututu-de-barriga-marela (Pulsatrix koeniswaldiana), caburé (Glaucidium brasilianum), coruja-do-mato (Strix virgata) e mocho-diabo (Asio stygius). Os resultados sugerem que as variáveis da estrutura da vegetação e composição influenciam na ocorrência de corujas. A altura do dossel, a presença de árvores ocas, árvores caídas e clareiras, demonstram que são os componentes estruturais mais influentes na distribuição de corujas na área amostrada.

Palavras-chave: estrutura da vegetação, floresta estacional semidecidual, Reserva Biológica das Perobas, Strigiformes.

\section{Introduction}

Birds of prey, as well as other animal groups, are not evenly distributed in the different habitat types that make up a landscape (e.g. Thiollay, 1994; Granzinnolli and Motta-Junior, 2008). Habitat selection by an animal is the result of its ecology, behaviour and physiology, or the interaction of these aspects (Cody, 1985; Tapia et al., 2007).
The biology of nocturnal birds of prey, such as owls, is less well known than that of daytime birds of prey, especially regarding habitat use and selection. Some studies conducted in the northern hemisphere have suggested a connection between owl distribution and features of vegetation structure or landscape (Solis Junior and Gutiérrez, 1990; Laidig and Dobkin, 1995; Carey and Peeler, 1995). Some owls, like 
Otus flammeolus (Kaup, 1853), are associated with areas that have glades around locations used for nest-making (Mccallum and Gehlbach, 1988), whereas individuals of Strix varia (Barton, 1799) require mostly closed canopy areas to use as a resting roost and dormitory during the day (Laidig and Dobkin, 1995). Understanding which characteristics of vegetation structure or landscape have impact on the occurrence of different species is important for conservation, especially of forest owls, which are potentially more sensitive to habitat fragmentation (Borges et al., 2004).

In Brazil, a study in the Amazon Rainforest revealed that the two sampled Strigiform, Lophostrix cristata (Daudin, 1800) and Glaucidium hardyi (Vielliard, 1990) had a more general distribution pattern that was indifferent to the types of vegetation (Sberze et al., 2009). Also in the Amazon Rainforest, Barros and Cintra (2009) conducted a study that evaluated the effects of forest structural components on habitat use by six Strigiform species. L. cristata and G. hardyi showed a distribution pattern concentrated in the most preserved areas of the centre of the forest, unlike Megascops watsonii (Cassin, 1849), which showed a concentrated distribution in forest locations with a higher frequency of broken but still standing tree trunks. In the Atlantic Forest, Amaral (2007) studied the habitat use of five species of forest owls and found that Strix virgata (Cassin, 1849) was the most specialised, confining itself to taller canopy points, whereas Megascops choliba (Vieillot, 1817) was a generalist, occurring in all areas.

The Atlantic Forest has been widely explored and fragmented in recent decades (Morellato and Haddad, 2000). In the north and northwest of Paraná state, the situation is no different. Due to advancing agricultural activities in those regions, the Atlantic Forest has been reduced, leaving less than $2 \%$ of semi-deciduous seasonal forest in the state's northwest (Ribeiro et al., 2009). The Perobas Biological Reserve, with 8,716 ha (ICMBIO, 2012) located in northwest Paraná, is the largest forest fragment across the north and northwest of the state, and is becoming an important refuge for the region's fauna and flora. The reserve is characterized by harbouring a contact zone between the seasonal semi-deciduous forest and mixed ombrophilous forest (ICMBIO, 2012).

Our working hypothesis is that owl species have different spatial distributions inside that Unit Conservation. This study aimed to identify which variables of the vegetation affect the spatial distribution of each owl species the most.

\section{Material and Methods}

\subsection{Study site}

The Perobas Biological Reserve $\left(23^{\circ} 47^{\prime} 23^{\circ} 54^{\prime} \mathrm{S}\right.$ and $52^{\circ} 41^{\prime} 52^{\circ} 50^{\prime} \mathrm{W}$; PBR), is located in the municipalities of Tuneiras do Oeste and Cianorte, in the northwest region of Paraná state (ICMBIO, 2012). The region's climate is characterized as humid subtropical type Cfa, presenting well-distributed rainfall throughout the year and harsh summers, according to the Koppen-Geiger classification (Peel et al., 2007). The region has altitudes ranging from 410 to $590 \mathrm{~m}$ (ICMBIO, 2012).

\subsection{Field procedures}

Eight sampling points were determined in the Perobas Biological Reserve (PBR), as can be seen in Figure 1. To sample the components of vegetation at each point, two $10 \times 10 \mathrm{~m}$ plots were marked with a distanced centre

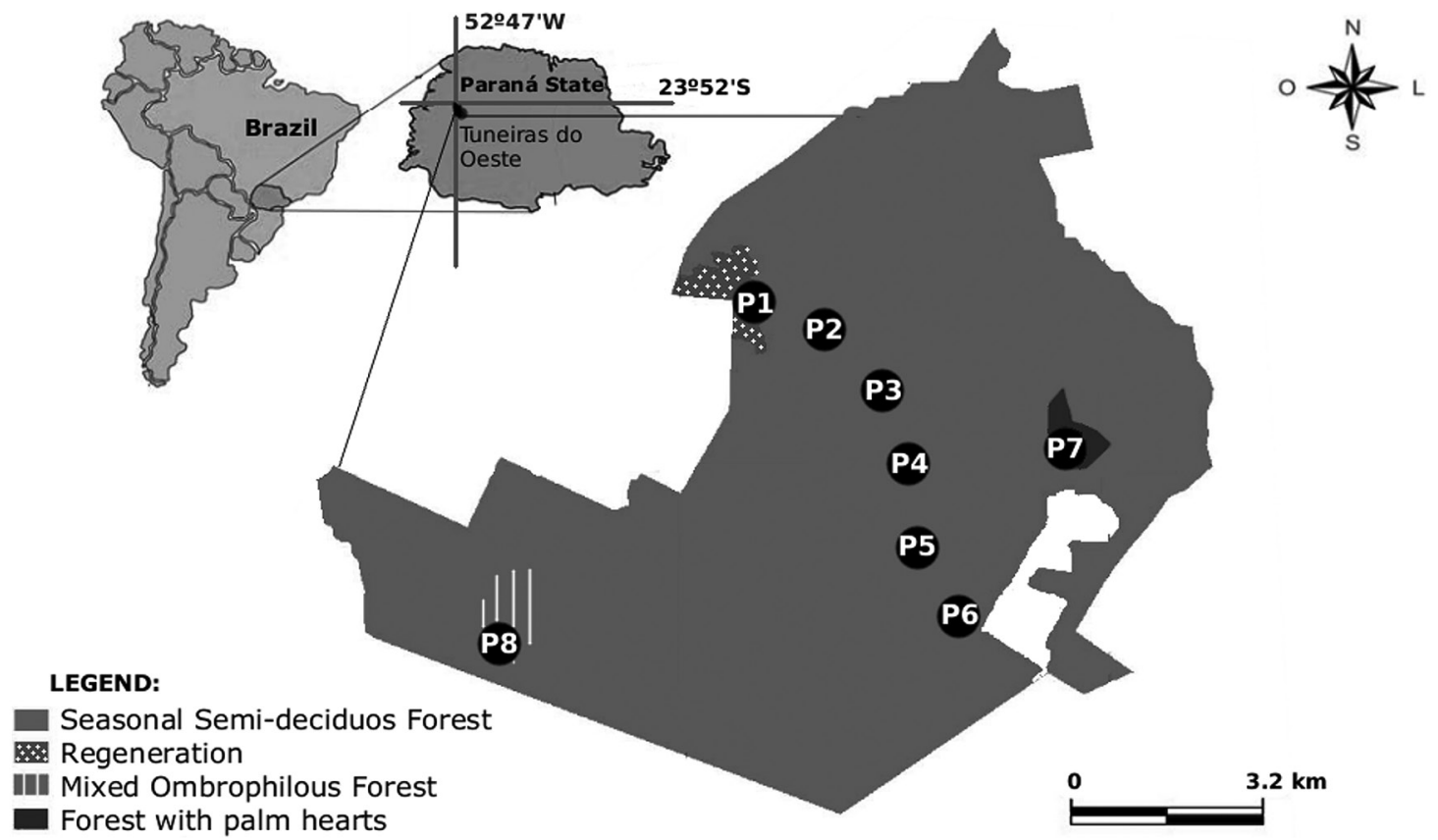

Figure 1. Location of sampling points at Perobas Biological Reserve, Tuneiras do Oeste, Brazil. Adapted from: ICMBIO (2012). 
$10 \mathrm{~m}$ to the north and south of the sampling point. Inside each quadrant, the following variables were recorded: average canopy height (ACH); presence of glade (GLA); abundance of climbing plants (ACB); abundance of shrubs $(\mathrm{ASH})$ and the presence of litterfall (ABL). The latter four variables were classified according to the following criteria: (1) absent; (2) present in up to $10 \%$ of the area; and (3) present in more than $10 \%$ of the area. The number of arboreal individuals with $\mathrm{CBH}$ (Circumference at Breast Height) from 50 to $90 \mathrm{~cm}$ (CHA), 91 to $150 \mathrm{~cm}$ (CHB), 151 to $210 \mathrm{~cm}(\mathrm{CHC})$, or $>211 \mathrm{~cm}$ (CHD); number of hollow arboreal individuals (HOL); and fallen trees (FAT) were also collected.

Owl censuses were conducted between September and December 2011, a period when the owls' vocal activities are more frequent, increasing the detectability of different species (Newton, 1979; Granzinnolli and Motta-Junior, 2008). Each point was sampled four times in a campaign in four different periods: dusk (17:00 to 19:00); night (19:00 to 21:00); early hours (00:00 to $02: 00)$ and dawn (05:00 to 07:00). The punctual detection radius was $150 \mathrm{~m}$.

To maximize auditory contacts with the owls, the technique of "playback" was used, which consists of reproducing recordings of owl species with historical records in Parana's Atlantic Forest. Potential species in the PBR were obtained from species lists of the region (Straube et al., 1996; Anjos and Bóçon, 1999; Straube and Urben-Filho, 2005).

After each playback, we waited for $3 \mathrm{~min}$, followed by another 2 min of playback and ending with a final 5 min of waiting for each owl species, thus respecting a probable period of lethargy (Mosher et al., 1990).

\subsection{Data analysis}

Each sampling point was considered a sampling unit (S.U.) and the vegetation's components were regarded as independent variables. To determine the abundance of each species at each sampling point, the maximum number of contacts obtained in a punctuate sampling was considered. This procedure, based on Bibby et al. (2000), is used for birds with low population densities, as in the case of nocturnal raptors.

To sort the vegetation's physiognomy at the sampling points from the variables, the Bray-Curtis index was used (Krebs, 1999) employing the Past Program, version 2.1.7c. To verify the distribution patterns of the owls and the influence of vegetation variables, canonical correspondence analysis (CCA) was used (Ter Braak, 1986) by means of the R program package "vegan" (Oksanen et al., 2011).

\section{Results}

Analysing the results of the vegetation variables, three sampling point groups could be be defined (Figure 2). The first group had mature wood, with large trees and high canopy heights ranging from 12 to $22 \mathrm{~m}$ (points 7, 3, 4 and $6)$. The second group had the physiognomy of regenerating forest, with a lower canopy, 7 to $9 \mathrm{~m}$ tall, few large and medium-sized trees and glades present more frequently

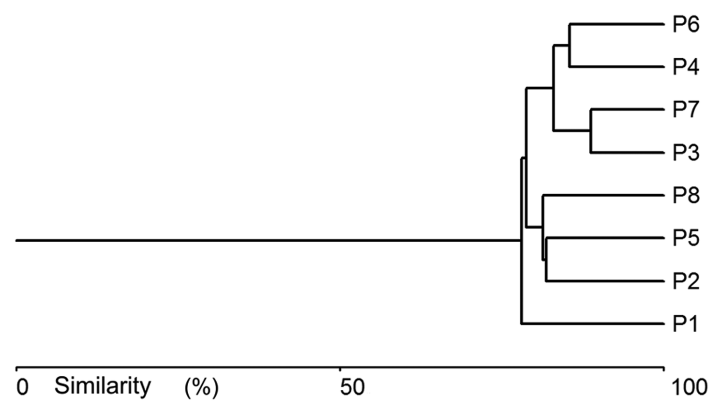

Cluster analysis

Figure 2. Similarity dendrogram (Bray Curtis) between sample points (P1-P8) in the Perobas Biological Reserve, Paraná, drawn by means of vegetation variables.

(points $2,5,8$ ). The third group was only represented by point 1 , possessing a swamp with some araucarias present.

Fifty six individuals from six owl species were recorded: Tropical Screech-Owl (Megascops choliba), Black-capped Screech-Owl (Megascops atricapilla; Temminck, 1822), Tawny-browed Owl (Pulsatrix koeniswaldiana; Bertoni \& Bertoni, 1901), Ferruginous Pygmy-Owl (Glaucidium brasilianum; Gmelin, 1788), Mottled Owl (Strix virgata) and Stygian Owl (Asio stygius; Wagler, 1832). The Tropical Screech-Owl was the most abundant species $(n=16)$ in the PBR and the Stygian Owl was the least abundant, with only one record.

Most of the sampling points exhibited the same species composition (Table 1), with small variations in the number of individuals. Point 4, located almost in the centre of the PBR, had all sampled species present and also had the largest number of individuals at a single point $(=10)$. Point 8 , located in the swampy area with araucarias, recorded just one species and two individuals.

Analysing the number of species recorded at different canopy heights according to their body weight obtained from the literature (Sick, 1997), it can be noted that owls with greater body mass (S. virgata, P. koeniswaldiana and A. stygius) had a larger number of records in areas with tall canopy, whereas owls with lower body mass (G. brasilianum, M. choliba and M. atricapilla) were distributed more homogeneously in the forest (Figure 3).

The results of the canonical correspondence analysis (Figure 4) showed significant distribution patterns. The first axis (CCA 1) explained $52.38 \%$ of the variance and axis 2 (CCA 2) 27.24\%. The variables considered significant in the spatial distribution of the owls were average canopy height $(\mathrm{ACH})$, presence of glade (GLA), abundance of climbing plants (ACB), number of arboreal individuals with $\mathrm{CBH}$ between 50 and $90 \mathrm{~cm}$ (CHA) and 91 or $150 \mathrm{~cm}$ (CHB), number of hollow arboreal individuals (HOL) and fallen trees (FAT). The CCA's results are spatialized in a diagram ("diplot").

The results suggest that M. atricapilla, S. virgata, G. brasilianum and P. koeniswaldiana are more abundant in environments with a greater number of arboreal individuals with $\mathrm{CBH}$ between 91 and $150 \mathrm{~cm}$, with fallen trees, 
Table 1. Maximum number of contacts with owls' species in the eight sampling points in Perobas Biological Reserve, Paraná, Brazil.

\begin{tabular}{|c|c|c|c|c|c|c|c|c|c|}
\hline Species & P1 & P2 & P3 & P4 & P5 & P6 & P7 & P8 & TOTAL \\
\hline $\begin{array}{l}\text { Megascops choliba } \\
\text { (Vieillot 1817) }\end{array}$ & 3 & 1 & 1 & 2 & 2 & 3 & 2 & 2 & 16 \\
\hline $\begin{array}{l}\text { Megascops atricapilla } \\
\quad \text { (Temminck 1822) }\end{array}$ & 1 & 1 & 1 & 2 & 1 & 1 & 2 & 0 & 9 \\
\hline $\begin{array}{l}\text { Strix virgata } \\
(\text { Cassin } 1849)\end{array}$ & 0 & 2 & 3 & 2 & 2 & 3 & 2 & 0 & 14 \\
\hline $\begin{array}{l}\text { Glaucidium brasilianum } \\
\text { (Gmelin 1788) }\end{array}$ & 2 & 1 & 2 & 2 & 2 & 2 & 2 & 0 & 13 \\
\hline $\begin{array}{l}\text { Pulsatrix koeniswaldiana } \\
\text { (Bertoni \& Bertoni 1901) }\end{array}$ & 0 & 0 & 1 & 1 & 0 & 0 & 1 & 0 & 3 \\
\hline $\begin{array}{c}\text { Asio stygius } \\
\text { (Wagler 1832) }\end{array}$ & 0 & 0 & 0 & 1 & 0 & 0 & 0 & 0 & 1 \\
\hline TOTAL & 6 & 5 & 8 & 10 & 7 & 9 & 9 & 2 & 56 \\
\hline
\end{tabular}

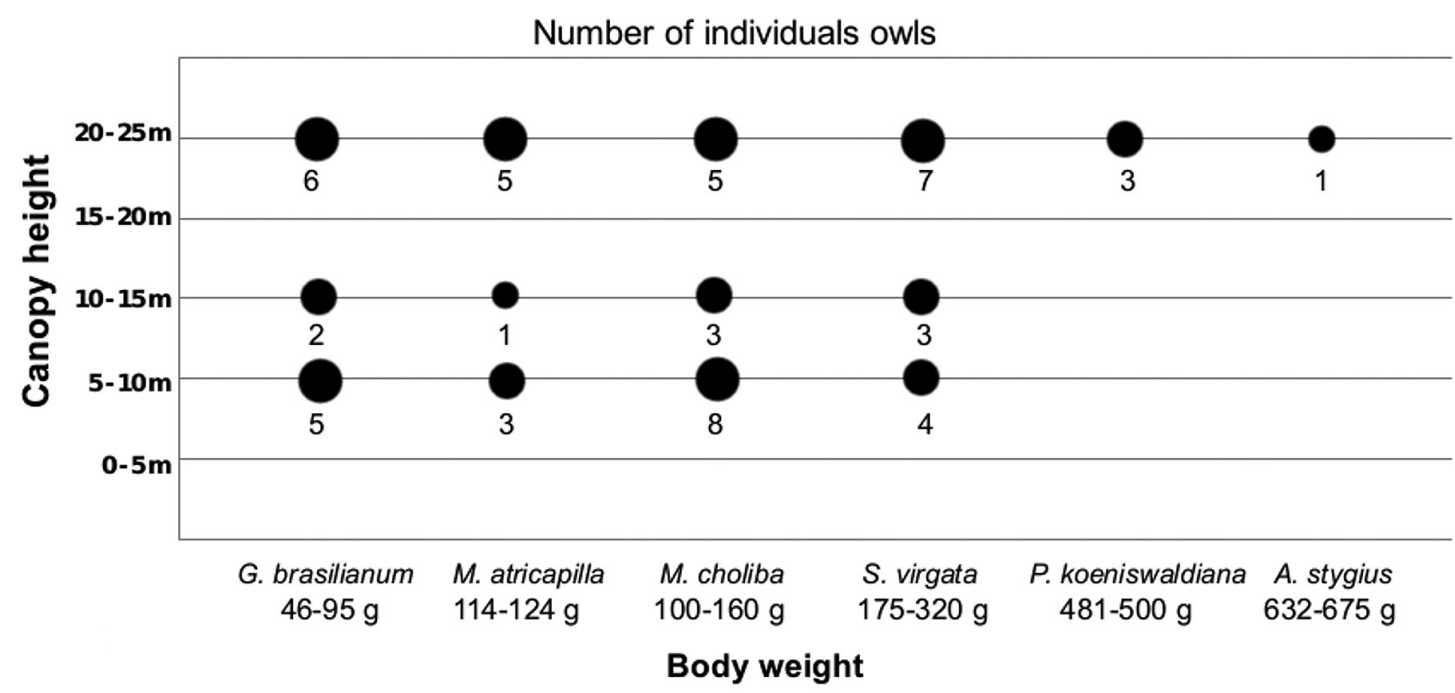

Figure 3. Number of records of owl species at different canopy heights according to their body weight.

hollow trees still standing, taller canopy and fewer small trees (CHA) and glades. On the other hand, M. choliba occurred in greater abundance in locations with higher frequencies of glades and small trees.

\section{Discussion}

The results obtained in this paper support the hypothesis that owls have different distribution patterns inside the sampled forest. The canopy height as well as the presence of hollow arboreal individuals, glades and fallen trees are the most influential variables in the owls' distribution in the PBR. The larger species are associated with forest areas with tall canopies, with a great abundance of still standing and fallen trunks, whereas the smaller species were distributed more homogeneously.

Strix virgata and P. koeniswaldiana used PBR areas with higher canopies. This characteristic of vegetation structure is typical of a most mature forest with a greater abundance of large trees, hollows and cavities with larger apertures that favour the occurrence of these species. These vegetation characteristics may also be associated with a greater variety of small mammals and birds (Kiltie, 1981), which are the main food items of both species, as noted by Sick (1997).

For some owls the presence of standing dead trees is an essential factor in choosing locations for nesting (Thorstrom et al., 2000). Barros and Cintra (2009) indicated a high density of L. cristata and M. watsonii in points with this trait. The results of this paper indicated that the presence of hollow arboreal individuals had greater influence on the occurrence of $S$. virgata and G. brasilianum, who use these locations for nesting (Sick, 1997).

Biological knowledge about M. atricapilla is scarce and no study has been conducted with reference to its habitat use and selection. Here, for the first time, detailed habitat information for this species is presented. It coexists with its 


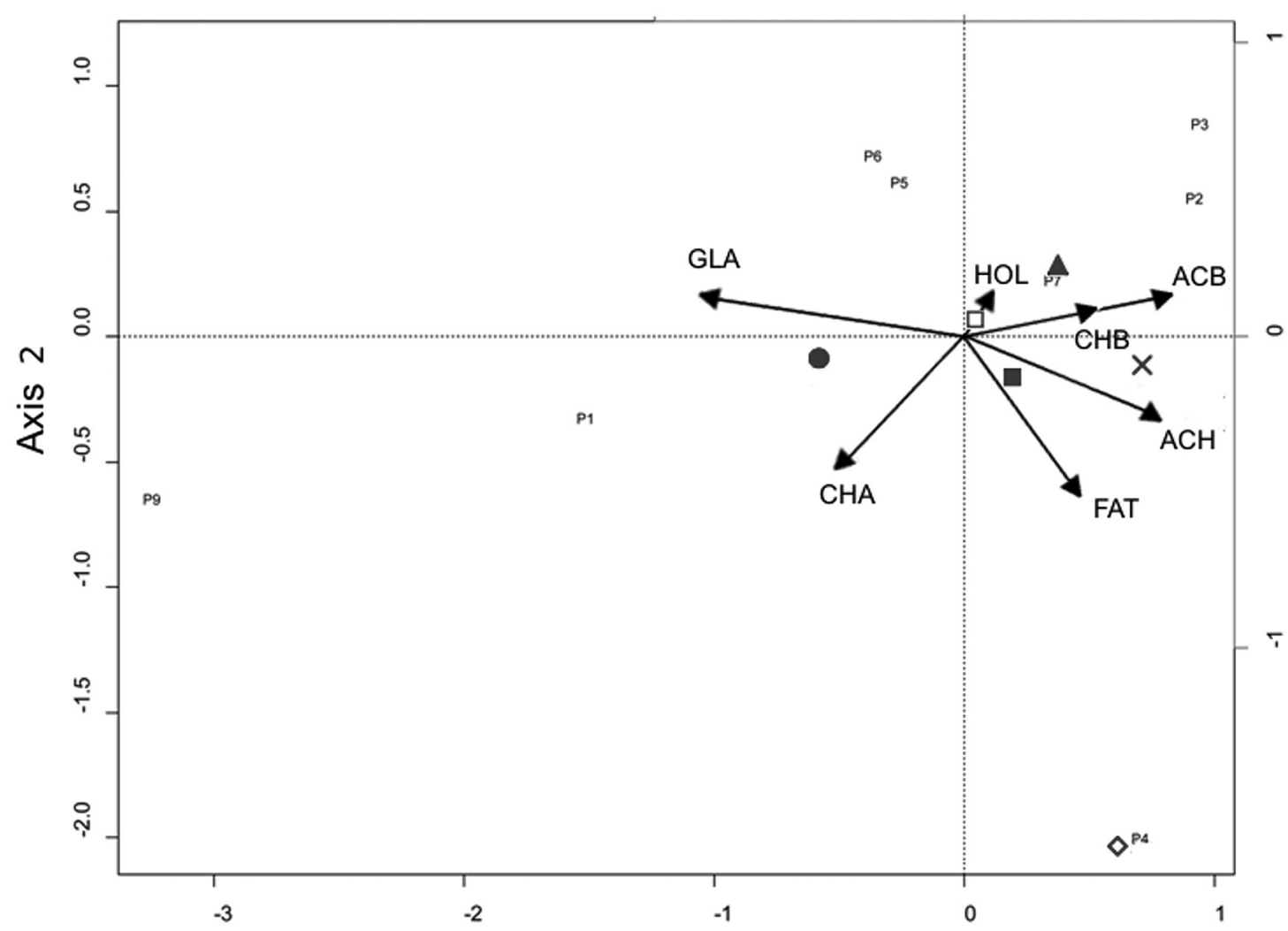

Axis 1

$\rightarrow$ Variables

- Megascops choliba

- Megascops atricapilla

- Strix virgata
Glaucidium brasilianum

$\times$ Pulsatrix koeniswaldiana

$\diamond$ Asio stygius

Figure 4. Ordination diagram of Canonical Correspondence Analysis (CCA). The diagram shows the distribution of owl species and vegetation variables on two ordination axes. Variables: canopy height (ACH), presence of glade (GLA), abundance of climbing plants (ACB), number of arboreal individuals with $\mathrm{CBH}$ between 50 to $90 \mathrm{~cm}$ (CHA) and 91 to $150 \mathrm{~cm}$ (CHB), number of hollow arboreal individuals (HOL) and fallen trees (FAT).

congener, M. choliba. It is known that $M$. atricapilla is a species associated with primary forests and M. choliba is more associated with the edges of woods and regenerating-stage forests (Sick, 1997; König and Weick, 2008). In the present study, $M$. choliba and $M$. atricapilla had more generalist patterns, occurring in forest environments with a great abundance of tall and large trees as well as areas with low canopies, glades and low tree abundance. M. atricapilla failed to be recorded only in a location where just a few trees and many glades predominated. Asio stygius, which is medium-sized, inhabits savannas and semi-open areas, using forests and forest borders for daytime rest (Sick, 1997; Konig and Weick, 2008). In this paper, A. stygius was more associated with fallen trunks; however, only one individual was sampled.
The six owl species found in the PBR represent about $42.8 \%$ of the number of forest owl species documented in southern Brazil, which could be considered a relatively high richness for such a small fragment (Straube and Urben-Filho, 2005; Scherer-Neto et al., 2011).

\section{Conclusion}

The canopy height, the presence of hollow arboreal individuals, glades and fallen trees are the most influential variables in the owls' distribution in the PBR. The larger species are associated with forest areas with tall canopies, with a great abundance of still standing and fallen trunks, whereas the smaller species were distributed more homogeneously. 
Some owl species are more tolerant while other species are sensitive to habitat requirements such as those related to food and breeding. Further studies involving these and other species in different vegetation types, are needed to confirm the patterns presented here and determine the habitat use of species in different types of vegetation.

\section{Acknowledgements}

We are grateful to JF Copatti, AG Cândido da Silva, DJ Ribeiro and CAF De Giovanni for helping us in the field work. We are grateful to Programa de Pós-graduação em Ciências Biológicas (UEL), CAPES, ICMBIO and Perobas Biological Reserve for allowing us to conduct this study. We are grateful to RJDF do Santos, for comments and suggestions, and to two anonymous reviewers of the manuscript.

\section{References}

AMARAL, K.F., 2007. Composição e abundância de corujas em Floresta Atlântica e sua relação com variáveis de habitat. Porto Alegre: Universidade Federal do Rio Grande do Sul, 47 p. Masters Dissertation in Ecology.

ANJOS, L. and BÓÇON, R., 1999. Bird communities in natural forest patches in southern Brazil. The Wilson Bulletin, vol. 111, no. 3, pp. 397-414.

BARROS, O.G. and CINTRA, R., 2009. The effects of forest structure on occurrence and abundance of three owl species (Aves: Strigidae) in the Central Amazon forest. Zoologia, vol. 26, no. 1, pp. 85-96. http://dx.doi.org/10.1590/S1984-46702009000100014.

BIBBY, C.J., BURGESS, N.D., HILL, D.A. and MUSTOE, S., 2000. Bird census techniques. 2nd ed. London: Academic Press. 302 p.

BORGES, S.H., HENRIQUES, L.M. and CARVALHAES, A., 2004. Density and habitat use by owls in two Amazonian forest types. Journal of Field Ornithology, vol. 75, no. 2, pp. 176-182. http://dx.doi.org/10.1648/0273-8570-75.2.176.

CAREY, A.B. and PEELER, K.C., 1995. Spotted owls: recurce and sapace use in mosaic landscapes. The Journal of Raptor Research, vol. 29, no. 4, pp. 223-239.

CODY, M.L., 1985. Habitat selection in birds. San Diego: Academic Press. 558 p.

GRANZINNOLLI, M.A.M. and MOTTA-JUNIOR, J.C., 2008. Aves de rapina: levantamento, seleção de habitat e dieta. In: S.V. MATTER, F.C. STRAUBE, I. ACCORDI, V. PIACENTINI and J.F. CÂNDIDO-JUNIOR, orgs. Ornitologia e conservação: ciência aplicada, técnicas de pesquisa e levantamento. Rio de Janeiro: Technical Books, pp. 169-187.

INSTITUTO CHICO MENDES DE CONSERVAÇÃO DA BIODIVERSIDADE - ICMBIO, 2012. Plano de manejo da Reserva Biológica das Perobas. Brasília: ICMBIO.

KILTIE, R., 1981. Distribution of palm fruit on a rain forest floor: why white-lipped peccaries forage near objects. Biotropica, vol. 13, no. 2, pp. 141-145. http://dx.doi.org/10.2307/2387716.

KÖNIG, C. and WEICK, F., 2008. Owls: a guide to the owls of the world. 2nd ed. London: Christopher Helm. 528 p.
KREBS, C.J., 1999. Ecological methodology. 2nd ed. Menlo Park: Benjamin Cummings. 620 p.

LAIDIG, K.J. and DOBKIN, D.S., 1995. Spatial overlap and habitat associations of barred owls and great horned owls in southern New Jersey. Journal Raptor Research, vol. 29, no. 3, pp. 151-157.

MCCALLUM, D.A. and GEHLBACH, F.R., 1988. Nest-site preferences of flamulated owls in western New Mexico. The Condor, vol. 90, no. 3, pp. 653-661. http://dx.doi.org/10.2307/1368355.

MORELLATO, L.P.C. and HADDAD, C.F.B., 2000. Introduction: the Brazilian Atlantic Forest. Biotropica, vol. 32, no. 4b, pp. 786-792. http://dx.doi.org/10.1111/j.1744-7429.2000.tb00618.x.

MOSHER, J.A., FULLER, M.R. and KOPENY, M., 1990. Surveying woodland raptors by broadcast of conspecific vocalizations. Journal of Field Ornithology, vol. 61, pp. 453-461.

NEWTON, I., 1979. Population ecology of raptors. Vermillion: Buteo Books. 399 p.

OKSANEN, J., BLANCHET, F.G., KINDT, R., LEGENDRE, P., O'HARA, R.B., SIMPSON, G.L., SOLYMOS, P., STEVENS, M.H.H. and WAGNER, H., 2011. R package version 1.17-7. Vienna: R Foundation for Statistical Computing.

PEEL, M.C., FINLAYSON, B.L. and MCMAHON, T.A., 2007. Updated world map of the Köppen-Geiger climate classification. Hydrology and Earth System Sciences Discussions, vol. 1, no. 2, pp. 439-473. http://dx.doi.org/10.5194/hessd-4-439-2007.

RIBEIRO, M.C., METZGER, J.P., MARTENSEN, A.C., PONZONI, F.J. and HIROTA, M.M., 2009. The Brazilian Atlantic forest: How much is left, and how is the remaining forest disturbed? Implications for conservation. Biological Conservation, vol. 142, no. 6, pp. 1141-1153. http://dx.doi.org/10.1016/j.biocon.2009.02.021.

SBERZE, M.R., COHN-HAFT, M. and FERRAZ, G., 2009. Oldgrowth and secondary-forest site occupancy by nocturnal birds in a Neotropical landscape. Animal Conservation, vol. 13, no. 1, pp. 3-11. http://dx.doi.org/10.1111/j.1469-1795.2009.00312.x.

SCHERER-NETO, P., STRAUBE, F.C., CARRANO, E. and URBEN-FILHO, A., 2011. Aves do Paraná: história, lista anotada e bibliografia. Curitiba: Edição dos Autores. 130 p. Hori Cadernos Técnicos, no. 2.

SICK, H., 1997. Ornitologia brasileira: uma introdução. Rio de Janeiro: Nova Fronteira. 862 p.

SOLIS JUNIOR, D.M. and GUTIÉRREZ, R.J., 1990. Summer habitat ecology of northern spotted owls in northewestern California. The Condor, vol. 92, no. 3, pp. 739-748. http://dx.doi. org/10.2307/1368693.

STRAUBE, F.C. and URBEN-FILHO, A., 2005. Observações sobre a avifauna de pequenos remanescentes florestais na região noroeste do Paraná (Brasil). Atualidades Ornitológicas, vol. 123, pp. 10-14.

STRAUBE, F.C., BORNSCHEIN, M.R. and SCHERER-NETO, P., 1996. Coletânea da avifauna da região noroeste do estado do Paraná a áreas limítrofes (Brasil). Arquivos de Biologia e Tecnologia, vol. 39, no. 1, pp. 93-214.

TAPIA, L., KENNEDY, P.L. and MANNAN, W., 2007. Habitat sampling. In: D. BIRD and K. BILDSTEIN, eds. Raptor research 
and management techniques. Washington: Hancock House Publishers, pp. 153-170.

TER BRAAK, C.J.F., 1986. Canonical correspondence analysis: a new eigenvector techique for multivariate direct analysis. Ecology, vol. 67, no. 5, pp. 1167-1179. http://dx.doi.org/10.2307/1938672.

THIOLLAY, J.M., 1994. Family Accipitridae (Hawks and Eagles). In: J. DEL HOYO, A. ELLIOT and J. SARGATAL, eds.
Handbook of the birds of the World. Barcelona: Lynx Edicions, pp. 52-205. vol. 2.

THORSTROM, R., RAMOS, J.D. and MORALES, C.M., 2000. Breeding biology of barred Forest falcons (Micrastur rufficollis) in northeastern Guatemala. The Auk, vol. 117, no. 3, pp. 781786. http://dx.doi.org/10.1642/0004-8038(2000)117[0781:BB OBFF]2.0.CO;2. 